\title{
Reducing Java's Transmigrant Conflict With Indigenous People through Multicultural Education
}

\author{
Deki Wibowo', Suyahmo ${ }^{2}$, Dew Liesnoor Setyowati ${ }^{3}$, Hamdan Tri Atmaja ${ }^{4}$ \\ ${ }^{1234}$ STKIP Melawi Kalimantan Barat, Indonesia \\ ${ }^{1234}$ Graduate School, Universitas Negeri Semarang, Indonesia \\ Corresponding email: wibowo.deki@yahoo.co.id)
}

\begin{abstract}
Melawi Regency is colored by various tribes, characterized by various cultures, languages, and religions embraced, and diverse cultural value system contained in the community. Dayak tribe is one of indigenous tribes located in Melawi, besides there are also the descendants of Malayu migrants such as Banjar, Java, Sunda, Madura, and China. The transmigration program entered into the Melawi region in 1984. It is conducted by the Small Dry Land Group in Tanjung Sari Village area. Since the application of the program, there happened some conflicts arising between transmigrants and indigenous people in Melawi. One of them is about land ownership and the boundary. Given the conflict between transmigrant communities and indigenous peoples, this research becomes important to give better understanding on how to conquer conflict by instilling multicultural education in Melawi. The purpose of this study was to analyze the occurrence of conflict sources between Javanese transmigrants and indigenous people in Melawi based on the perspective of trinity theory. The method used in this research was qualitative research approach. The results of this study showed that the source of conflict between Javanese transmigrants and indigenous people in Melawi could be overcome by the theory of trinity Piere Bourdieu which states that habitus, social modality and arena are key to social reproduction because it is central in generating and regulating practices, practices that shape social life.
\end{abstract}

Keywords: reduce conflict, multicultural education

\section{Introduction}

West Kalimantan, especially Nanga Pinoh Sub-district in Melawi Regency is one of the provinces and regency in Indonesia. The regency consists of various ethnic groups characterized by a variety of cultures, languages, dialects, religions adopted, and diverse cultural value system contained in the community. However, there was a social conflict that happened between 1999-2002 and involved Dayak, Malay and Madura. It started from a private problem and further affected a group or a tribe, and has never involved the whole tribe that leads to nuanced conflict.

The previously mentioned tribal people of Java roaming in Melawi district, in the beginning followed the transmigration program held by the government since the New Order era was renamed in 1974 until now. The Old Order under Sukarno and the New Order under Suharto put forward the spirit of uniformity with an authoritarian system, not an effort to encourage people to accept voluntary differences. In addition, the transmigration policies of the New Order brought significant influences in the form of population flows from densely populated areas of Java, Madura and Bali, to rare areas in Kalimantan and East Indonesia.
The transmigration program entered Melawi Regency, particularly in Nanga Pinoh Sub-district In 1984 (West Kalimantan Provincial Manpower and Transmigration Office). It is called the Small Group of Dry Land (SGDL) in Tanjung Sari Village area. The purposes of the implementation of the transmigration program in Melawi District are: First, to improve the welfare of the population who follow the program. Second, to send communities from trained Java Island transmigration sites with hope that Javanese can build local transmigrants. Third, to implement pre-established development programs by the government such as agriculture, plantation, education, as well as the construction of roads, street, education facilities, health facilities and other supporting facilities.

The main purpose of the central government is the equitable distribution of development throughout the archipelago nationally, especially in disadvantaged areas such as in Melawi Regency, Nanga Pinoh Subdistrict, West Kalimantan. The problems that occur in transmigrant policy in Indonesia generally and especially in Melawi Regency regarding the implementation of transmigration programs in Melawi Regency, Nanga Pinoh Sub-district, West Kalimantan, namely first, the 
problem with the origin of the transmigrants. Second, the socio-cultural clash between the immigrant population and the native/local population. Third, the cooperation with the local government or related agencies related to the transmigration policy which is not maximal. Thus, it will create a new problem, namely the presence of migrant populations such as transmigrant communities in Melawi Regency in general will cause social frictions such as social, economic, and cultural gaps. Similarly, it also occurs to language barriers, and most cannot yet accept the presence of migrant communities. This is one of the major homework for the Melawi Regency Government to self-engage in the settlement, not to trigger a horizontal conflict such as on $19^{\text {th }}$ of January 1999 between Sambas and Madurese Tribes.

The conflicts occurred between transmigrant communities and indigenous people in Melawi Regency Nanga Pinoh Subdistrict, West Kalimantan are such as the conflict over land used by Transmigrant people for agriculture recognized by local community as customary land, which legally should have been handed over by the government of Melawi Regency to the community of transmigrants for agricultural land, boundary conflicts that often occur between sub-districts in the region Melawi. This occurs after the investor entered the territory of Melawi Regency concerned to opened a new land for oil palm plantation. This act apparently triggered a conflict in the Regency of Melawi.

Another conflict arising between transmigrant communities and indigenous peoples is concerning about land ownership and boundaries. This problem resulted in the absence of tranquility in work and in their daily life. This will also affect children. Therefore, the need for multicultural education is formalized into a policy because the people in the pluralist Melawi Regency are connected with the phenomenon of conflict between community groups. Multicultural education is a response to the development of diversity as well as the demands of equal rights for each group. It can be interpreted that multicultural education is an education that encompasses all students regardless of their groups, such as gender, ethnicity, race, culture, social strata, and religion.

The purpose of this study was to analyze the occurrence of conflict sources between Javanese transmigrants and indigenous people in
Melawi based on the perspective of the trinity theory.

\section{Method}

The method used in this research was qualitative research approach. Data collection techniques used were observational research (observation), interviews, and documentation. Interviews. Those were conducted to transmigrant communities and indigenous peoples in the village of Tanjung Sari Small Group of Dry Land (SGDL). These informants were asked to provide sources of conflict that occurred in the area of transmigration. Meanwhile, the data analysis technique used in this study was the data analysis technique according to Miles and Huberman's theory (1984) who confirm that activities in the analysis of qualitative data are supposed to be conducted interactively and continuous to complete, so the data saturated. For more, the activities in data analysis covered data reduction, data display, and withdrawal of conclusion / verification.

\section{Results and Discussion}

Research on reducing Javanese transmigrant conflict so far has been done by some researchers from abroad and Indonesia who wrote about the study of transmigrants in Indonesia. However, this study only used some literature to illustrate the concept of problems about transmigrants in Nanga Pinoh Sub-district, Melawi Regency, West Kaimantan. Here, for example, the researcher got a picture from Sri Edi Swasono and Masri Singarimbun's research (1986) regarding problems that occurred in transmigration program in Indonesia. The problem of is caused by cultural contact between the Javanese transmigrants and the indigenous population. The cultural contact is due to a new cultural encounter with the old culture. If not addressed properly, it will cause friction or conflict between the population of Javanese transmigrants with the natives. Various friction or conflict can occur due to social disparity factors between immigrant population (Javanese transmigrants) with indigenous people (Dayak).

The source of conflict between transmigrant communities and indigenous people in Melawi Regency, Nanga Pinoh Subdistrict, West Kalimantan was the conflict over land used by Transmigrant people for agriculture, recognized by local community as customary land, which legally should have been 
handed over by the government of Melawi Regency to the community of transmigrants for agricultural land. There are also boundary conflicts that often occur between sub-districts in the region Melawi These occur after the investor entered the territory of Melawi Regency and concerned to open a new land for oil palm plantation. This obviously triggered a conflict in the Regency of Melawi.

According Swasono, usually migrants' economic life is much better than the original citizens. He took an example from what happened in East Kalimantan, South Kalimantan, and Central Kalimantan. Transmigrants in this region have succeeded in changing the fate of migrant populations, whereas for the natives, it is perceived as failing to their prosperity.

Heeren discussed the problem of transmigrants in Indonesia, specifically in South Sumatra in 1952-1958. His explanation begins by questioning the need for a transmigration program in Indonesia. According to Heeren, there are several factors influencing the Indonesian government to continue this program. First, the increasing number of people in Java island will result in the unabsorbed human resources by labor force. Second, national development is considered as unfair to every region because it is only concentrated in Java Island. Therefore, the government continues the transmigration program with the aim of being able to move the population while providing new jobs at the transmigration site. (H.J. Heeren).

Rukmadi Warsito (1984) describes the various problems that occur in transmigration policy in Indonesia. According to Warsito, there are three fundamental issues that occur in the implementation of transmigration programs in Indonesia. First, problems with transmigration areas. Second, the socio-cultural clash between the migrant population and the local population. Third, the non-maximum cooperation with related agencies related to transmigration policy. In the same case Rukmadi Warsito explaines that the policy of transmigration occurred because of the social problems of society on the island of Java-Madura and Bali that has occurred since the Dutch colonial period. The problem of poverty and lack of land for agriculture forced the Dutch East Indies government to run an Ethical Policy aimed at improving the socio-economic conditions experienced by rural communities on the island of Java. The Dutch East Indies colonial government implemented this program with the aim to overcome the socio-economic problems experienced by rural communities of Java Island.

According to Wasino, W. (2007) in his writing, when Indonesia was born as a national country, Indonesia was not a new entity. It was a historical continuation of a society called the Dutch East Indies. The people under the Western colonists were plural societies. Those were societies that were segregated by social class, ethnicity, religion, race, and interclass. For more, rulers and people were separated racially. In addition there was a tribal division related to economic, education, and social relations. After Indonesia's independence, the situation of plural society continued. The end of the New Order has opened the box of pandora about bad relations between ethnic and interreligious. As a result there were many conflicts based on ethnic and religious differences. It was increasingly tapered when political interests enter. The process of political reform gave rise to a new awareness of inter-ethnic and religious relations. The starting point of this changed when President Abdurrahman Wahid opened the barriers of multicultural relationships that respected differences in cultural orientation among ethnic groups. Since then, the concept of multiculturalism experienced a process of socialization in Indonesian society.

The following is presented the social environment of the community in the area of Tanjung Sari Village Dry Land Working Group (KKLK) which experienced social conflict with the indigenous people in the village of Tanjung Sari, Nanga Pinoh Sub-district. It can be seen from the interviews that have been done with transmigrant communities and indigenous peoples as follows:

Interviews dated 02-03-2018 together with Mr. Eviyantono, head of Community Empowerment Institution (LPM) in dry land working group of tanjung sari village. He said that in the community of transmigrants the issue which is always raised in the community is always the problem of indigenous and non natives people who have a personal interest in the local environment. Conflicts over land ownership issues or land for cultivation and plantation, which in fact legally have been handed over by the central government in 
collaboration with the district government of Melawi, handed over the whole community of Javanese transmigrants to agriculture. However, this was in contrast to the indigenous people in which they said that the land used by migrant communities is their customary land.

Interview dated 03-02-2018 with $\mathrm{Mr}$. Suprihatin the head of Youth Organization (Karang Taruna) of Tanjung Sari Village said that the economic gap that occurred in the transmigrant area between immigrants with the indigenous population was wrong. It further triggered the occurrence of social jealousy. For more, facilities such as road, electricity, water, that exist in the transmigrant area made indigenous people feel there is injustice in pasiltas development by the government. This was a strong indication of a social conflict in the community of Tanjung Sari Village.

The contents of the indigenous tribes statement about the existence of transmigrant communities, the meeting on Thursday 1 December 2016 statement attended by Dayak Kebehan figures, religious leaders, dayak kebehan youth figures, Bohan Hamlet who became transmigrant settlements stated that:

1. We, Dayak Kebehan (indigenous) community as trans insertion does not accept Javanese transmigrants as village heads who do not understand the origin of the region and the culture of Dayak kebehan customs.

2. We as transfers of Dayak kebahan community will move our Family Card (KK) to our home village, from Bohan Village to Poring Village because the land inhabited by transmigration will be pulled back. This letter of statement is in accordance with the letter of introduction No: 045/108 / Tapen C which we only submit as much as 10 $\mathrm{Ha}$ according to the letter of handover as of 31 December 2003 attached.
3. Waiting for this process, bordering the territory and including ball field, mosque, MI, polindes, and cooperative office will be run or implemented. If the Sub-district Leadership Conference ( Muspika) and the regency cannot solve this case, then we , Dayak Kebehan community can solve itself.

4. We, Dayak Kebehan community will ask for compensation of land area of $120 \mathrm{Ha}$ from 60 families. Each head of the family has a land area of $2 \mathrm{Ha}$ of land will be charged Rp. 50,000,000 per ha.

5. We, indigenous leaders or have not been able to receive transmigration people to bear a leader at the Village level as long as the debts in the LG have not been paid.

6. Our indigenous people of Bohan village will withdraw the land placed by transmigration program based on the SK certificate in Tanjung Tengang Village.

7. The land of indigenous people in Blocks of Society 7 and Blocks of Society 8 in 1982 ago totally failed of 150 hectares which was already in the lot by Umar's brother and sold and traded so that now has been made rubber plantation by the buyer of each plot -something.

Based on that exposure, it can be concluded that the conflict between Javanese transmigrants and the indigenous people in Tanjung Sari Village, Nanga Pinoh Subdistrict, Melawi Regency, was the social jealousy of the local community in Tanjung Sari Village. In Koentjaraningrat's study (1984), it is found that conflict of bias occurs when: (1) competition between two or more ethnic groups in terms of obtaining the same livelihood field; (2) imposition of cultural elements to the citizens of one tribe; (3) coercion of other ethnic groups of different religions to embrace a particular religion; (4) efforts to dominate other tribes politically; (5) the existence of hidden conflicts between ethnic groups that have been adat hostile. 


\section{Conclusion}

The social conflict occurring in the Tanjung Sari Village area between the Javanese transmigrant community and the indigenous population is a disagreement between members or groups in a comprehensive society caused by some differences. including, individual, cultural patterns, social status, interests and the occurrence of social change. Gillin and Gillin (1948) see the conflict as part of a process of opposing human social interactions. That is, conflict is part of the social process that occurs because of differences in both physical, emotional, cultural, and behavior. In other words, conflict is one of the social interaction processes that is dissociative. Morton Deutsch (Bunyamin Maftuh, 2005) states that in conflict, social interaction between individuals or groups is more affected by differences than by equality. Meanwhile, according to Scannell (2010) conflict is a natural and normal thing that arises because of differences in perception, purpose or value in a group of individuals.

\section{References}

Bunyamin Maftuh. (2005). Implementation of Conflict Resolution Learning Model through High School Senior Citizenship Education. Dissertation (unpublished).
Universitas Pendidikan Indonesia, Bandung.

Gillin, John Philip dan John Lewis Gillin. (1948). "Cultural Sociology". A Revision of An Introduction to Sociology" Macmillan Co.

H.J Heeren. (1979). Transmigration in Indonesia. Jakarta: PT Gramedia,

Koentjaraningrat. (1984). Javanese culture. Jakarta: PN Balai Pustaka.

Morton Deutsch, (1977). The Resolution of Conflict: Constructive and Destructive Processes (Carl Hovland memorial lectures). Yale University Press.

Miles dan Huberman.(1992).Qualitative data Analisis. London: Sage Publication.

Miles, B.B. \& A.M. Huberman. (1992). Analisa Data Kualitatif. Jakarta: UI Press.

Warsito, R. et al. (1984). Transmigration From Region of Origin to Cultural Clash in Residential Area. Jakarta: C.V. Rajawali.

Scannell, Mary. (2010). The Big Book of Conflict Resolution Games. United States of America: Mc Graw - Hill Companies, Inc. 